I should like to say something about the use of the word "functional," as to the propriety of which Dr. Dickinson leaves us in some doubt. He admits that "it has its uses" and would apply it "provisionally to disorders of a temporary sort which have not yet displayed their morbid anatamy," but considers it "mo:t obviously out of place when attached to such as persist unto death and produce it" (p. 1630). A little later he appears to sanction the definition of a functional disease as one "without a pathology, distarbanse of action unattencled with change of structure." Now, wall deference I wish to submit that this use of the word is too exclusively that of the morbid anatomist. That change of fanction implies a physical change of some sort $i$ an axiom to which no exceptions should be allowed. But there are physical changes which cannot be appreciated by morlid anatomy alone, which is concerned only with such changes as can be demonstrated to the eye by some process of "cutting up" dead and cliseased organs. A "functional" disease to the morbid anatomist is a purely megative conception. Pathology, however, is a kingdom of many provinces, among which morbid anatomy is but one, and though a large and important area is hardly at present so large or so important as that of pathological chemistry. From the point of view of the chemical changes which take mlace fin the cells of the body during disease the term "funceional" has a very positive meaning and I venture to think that thes meaning-namely, a change in chemical action or structure is the one which should occur to the mind whenever the term is employed. Far from impeding the adrance of knowledge such a u-e of the word enables the mind to earry on its inquiries at the point where morbid anatom leates of and sugrests investigations on new lines and by other methods.

Chorea offurs, to my mind, an excellent example of functional disease, but not of a direase without a pathology. The morbid anatomy does not tell us much, as the lesions described may well be secondury or symptomatic and not causative in eharacter. Even allowing that all cases of chorea are ret due to the same causo, it seems most probable that many, if not most of them, are like tetanus due to a specinc maicro organism--namely, the micrococcus rheumaticus described by Paine and Pornton. Like tetanus it is a disease characterined by muscular contractions, and tliough these cosetractions do not appear in so definite an order or in such regulas degrees of intensity, yet the occurrence of hemichorea and ehorea limited to certain groups of muscles indicates the definite involvoment of certain cells in the motor tract. Now in tetanus it is known that the toxin has a suecial affinity for cutain motor cells and enters into so Grm a combination wh them that in some cases no recovery is possible. In rabies, too, the ver y elusive poison can be meutralised by an emulsion of brain cells and thus rendered harmless to susceptible animals. May it not be that in chorez certain motor nerve cells are similarly poisoned but that the chemical change is of a less stable character, so that dissocit ition and recovery are generally possible?

This is a view which has for some time been present in my mind and doubtless in the minds of many who have considered the question. It serves, I think, to illustrate the sense which the term "functional" should be used in mathology, not as a pure negation but as expressing the goosite ve idea of changes which are none the less physical in that they cannot be demonstrated by the ordinary methods of the dead-house or even by the more refined "cutting up" which is necessary for microscopical examination.

I am, Sirs, Jours faithfully,

J. M. Fortescue-Brickdale, M.A., M.D. Oxon. Clifton, Dee. 12.th, 1904.

\section{THE EVOLUTION OF MAN'S DIET.}

\section{To the Editors of THE LANCET.}

Srnot, - In his kind reference to my papers on the Evolution of Man's Diet, recently published in THE LANCET, Dr. J. Sim Wallace (in 'THE LANCE'T of Dec. 17th, p. 1751) throws doubt on my contention that man " has lost the power of digesting in the unprepared state all but the very choicest varieties of wild vegetable food." He believes, on the contrary, "that man has it in his power to become able to digest or to cope withi cellulose to all intents and purposes as efficiently as the anthropord apes," and even hints that man and the apes differ but little in respect of dioestive capacity. Without coldowing Dr. Wallace in the a priosi arguments he advances in favour of this view, I will content myself with referring to the great biological fact that every species tends to alter in correspondence with alterations in its environment. Now, the diet of man and his homo simian ancestors has been undergoing a steady change since anthropoid times-i.e., for many thous.nds of generations, and we may therefore safely conclude that the cligestive capacities of man differ very decidedly from those of his anthropoid ancestors. Observation confirms this deduction. It would be quite impossible for man to subsist on the natural diet of any of the existing anthropoids. Much of the vegetable food which these latter consume is by reason of its natural density, to say nothing of its bitter and acrid taste, quite unfit for human consumption. This density is, of course, due to the presence of an abundance of tough cellulose, a fact which renders it highly probable that the anthropoid can cope with cellulose more efficiently than can man. Dr. Wallace appears to assume that the rôle of cellulose in the alimentary truct is a purely mechanical one, for be sars, "if we consider the simple fact that cellulose is not digested chemically in either man or anthropoids practically all we have to consider is the ability to masticate fool and to trans. mit it. Thus, all that is required is a more muscular intestine and especially a more efficient masticatory apparatus." I cannot, however, admit the proposition that "cellulose is not digested chemically in either man or anthropoids." It is true there is no evidence of the secretion either in man or the anthropoid, or indeed even in the herbivora, of a cellulose-dissolving ferment. There is, however, evidence that in all of them cellulose in its less dense forms is dissolved by bacterial agency, and it has been shown in the case of the herbivora that the solution is largely effected bv means of a regetable ferment developed froin the regetable food itself-a ferment identical with that which the living plant employs when a solution of cellulose is demanded-e.g., during the ripening of a fruit

But while I am unable to accept all Dr. Wallace's deductions I am heartily with him in his main contention that man is capable of coping with much coarser vegetable foods than the pernicious paps and messes with which the stomach of the young human is nowadays so wantonly deluger. It is, as Dr. Stuart Tidey truly remarks, ${ }^{3}$ largely in consequence of this system of dietary that the digestive tract of us moderns is so often "a pathological specimen from end to end," that "the buccal cavity exhibits a picture of ruin and decay ..... the anal orifice is girt about with a ring of piles, while the intervening portion with its accessory organs afforls a kaleidoscopic picture of pathological changes." If phrsicians could be got to realise the importance of providing the jaws, teeth, and the muscular coats of the digestive tract with adequate work an untold amount of disease and suffering would be averted. I am, Sirs, yours faithfully,

Wimpole-street, W., Dec. 18th, $1904 . \quad$ HARRY CAMPBELL

\section{TREATMENT OF ACUTE PNEUMONIA BY CONTINUOUS COUNTER-IRRITATION WITHOUT VESICATION. \\ To the Editors of THE LANCET.}

SIRS,--The treatment of pneumonia by various forms of counter-irritation is of very old standing. Linseed-meal poultices with and without mustard, blistering fluid, iodine liniment, and similar preparations have been applied to the chest with success but with the great disadvantages of more or less severe vesication or some other drawback. The following simple method of applying counter-irritaticn without vesication bas in my hands proved itself to be an ex cellent system of treatment. After making a thorough examination of the chest I sponge the affected side over with warm water, adding some alcohol (either rectified spirit of wine or whisky) which I always do to increase the irritation unless the skin be very tender or sersitive. Then I quickly apply thermogen or a capsicum pad which are much more easily applied and so do not exhaust the patient. The effect is to produce a dry glowing warmth and pain is relieved almost immediately. The application is never sticky or cold, t can easily be destroyed when required, and is perfectly cleanly. It is necessary only to replace it once or twice in the 24 hours, the medical attendant knowing that the patient's 
strength is not being unnecessarily lowered by continuous applications every few hours and that there is no danger of exposure to sudden change of temperature or draughts. From a patient's point of view, which is really of most importance, it is very comfortable, as it is neither wejghty, wet, nor sodden, but is dry and gives a glowing warmth that relieves pain. The patient is also saved the fatigue inciclental to an application that requires renewal every few hours.

I am, Sirs, yours faithfully.

ARNOLD M. ST. JOHN WRIGHT, L.S.A.

Chester, Dec. 18th, 1904.

\section{THE "POLICE CALL."}

To the Editors of THE LANCET.

SIRs,-Having read the article in THE LANCET of Dec. 17th, p. 1742, regarling the responsibility of the police for payment of services rendered at their request in cases of street accidents, \&c., I may be allowed to recall a recent experience of my own.

A policeman called and informed me that a man had been knocked lown by a tram-car and requested me to accompany him to the scene of the accident. Having received his assurance that a certificate would be sent to me in due course and having noted the constable's number for future reference I went and did what was necessary for the patient. Next day the policeman called again but instead of giving me the promised certificate he informed me that a friend of the injured man, whose name and address he gave me, had undertaken to pay $m y$ fee and that therefore no certificate would be sent to me from the police station. I questioned the right of the police authorities to refer me for payment to a man who was quite unknown to me but expressed my willingness to wait a few days before making formal application for my certificate. I reminded the policeman of his promise when he summoned me to the accicient; also of the fact that I had his number recorcled in my note-book.

A week passed and, needless to say, the obliging friend made no sign. I therefore sent a strongly worded letter to the inspector on duty informing him of all the circum. stances and questioning the policeman's right to shift his responsibility on to other shoulders. My certificale for Fayment from the police fund was sent immediately with a note apologising for the delay. Since then $I$ have in all cases obeyer the summons of a policeman only on the distinct understanding that I should receive my certificate flo:n the authorities and have invariably received it.

I am, Sirs, rours faithfully,

T. R. HENDERSON, M.B. Edin.

Ba!ham, S.W., Dec. 18th, 1904

\section{THE PRE-CANCEROUS STAGE OF CANCER. To the Editors of THE LANCET.}

SIRs,-I think we are entitled to ask for some further information on this subject, for it seems to convey nothing unless it means that every growth must be removed as soon as found in case it may become malignant and that every tear of the uterine cervix is to be sewn up. It is at least reasonable to suppose that a prolonged irritation of a part, due to the presence of a tumour or otheraise, may lessen its vitality and in this way be apparently the exciting cause of malignant disease in a suitable subject, but cancer of the penis may come to the circumcised and the uncircumcised and epithelioma of the lip is not unknown in those who do not smoke.

It is another matter when we come to the instruction of the laity in the early signs of cancer. Here we deal with no hypothetical pre-cancerous stage, but with the definite disease. Mr. C. Hamilton Whiteford advises that the public should be educated in the early signs. Surely this is going a great deal too far, for what would be the result-a graduate in first aid would consider that if he were able to say that a growth was a cancer, he could say equally well what were not cancerous, and in most cases, it would be as safe to toss up a coin. What the public require to be taught is to seek advice early and not to think that they know when to ask competent advice and when not. We require to begin, however, with many medical men, who do not investigate when a simple diagnosis seems to be a likely one and who, when' a patient says "I bave got bleeding 'piles, doctor," give an ointment without troubling to see if there is anpthing else. I allow that the patients frequently do not see the necessity of an examination. Mr. Whiteford alco says that the laity must be educated in the prevention and cure of cancer. We get enough of the cure in the daily papers, but I would like to hear of some really practical method of prevention.

Dec. 19th. 1903.

I am, Sirs, yours faithfally

\section{MOSQUITOES ON BOARD SHIP.}

To the Editors of THE LANCET.

Sins,-In his able categorical reply to the exiticisms of Professor Baccelli, whose disparagement of the work of the modern investigators of tropical diseases is amazing, Dr. C. Christy regards the presence of malaria on vessels as due to its transmission by passengers off river steamess. He also, it is true, refers to the presence of both anopheles on steamers between Karachi and Trieste. While diffident of making the suggestion to a medical man so closely associated with work in malarial comatries I am tempted to ask whether Dr. Christy has not overlooked, at any rate in his letter, a very important breeding ground of these gnats on board ship-namely, in the residue of rain water in the ship's buckets, in freshwater tanks, boats, or other receptacles insufficient]y crutinised on the official rounds of inspection. I have travelled on a steamer from estuaries in tropical Queensland to Plymouth Sound with mosquitoes active in the saloon the whole lime on a royage that laster nearly 80 dajs, and as Major R. Ross states that the larval stage may last only a week in a hot climate it is probable that some of these insects completed their metamorploses on the royage. A more efficient scouring of all likely receptacles of fresh water would preclude such unrecorded birth s at sea,

I am, Sirz, yours faithfully

Bournemouth, Dec. 17th, 1904

F. G. ATLSD.

\section{REX $r$ JOHN DALE TUCKER : THE POWERS OF THE GENERAL MEDICAL COUNCIL.}

\section{To the Editors of THE LANCET.}

SIRs,-This man, an unqualified practitioner, was tried at the recent Liverpool assizes on a charge of attempling to obtain money by false pretences and being found gailizy was sentenced by Mr. Justice Phillimore to four monthis' ingris onment. The circumstances of the case are so far ond of the ordinary that on behalf of the prosecutor, Dr. Davie da ader Lindsay of this city, we write to place them before $y$ on, believing that they will be of some interest to the medical profession. Briefly the facts are as follows.

In April of this year Tucker came to Liverpoof and in the name of Dr. Henry Gould, a duly qualified man, practice from Dr. Wright of this city, for whis he gave £350. He carried it on until the month of August when be entered into negotiations, still in the name of Dr. Henry Gould, with our client, for the sale of the practice to bim. He informed Dr. Lindsay that he, Tucker, was Dr. Heary Gould, a duly qualified man, and had given $\mathcal{E} E 0$ for the practice and had been in it for 12 months. As agrefment was accordingly drawn up but fortunately just be same was signed, owing to information which came into the possession of the vaccination officer of the distriet in which Tucker practised, he was brought up at the police-comat and charged with forging two death certificates in the mame of Dr. Henry Gould, when he pleaded guilty and was ined. Dr. Lindsay of course repudiated all negotiations and lajd an information against l'ucker, upon which he was arsested and in due course committed for trial and convictecl.

Having regard to all the facts at our disposal we consisered the case one which should be laid before the General conncil of Medical Education and Registration, as we did not think it right that a young practitioner should be put to the great expense of prosecuting criminal proceedings with the object of punisbing a man whose offence consisted in posing as a duly qualified man. We therefore saw the Registrar of the Council and put the whole facts before hiss, wen he seemed by no means inclined to give any assistance. He intimated, however, that if we were to lodge the facts with a written statement he would lay them before the Council. This we accordingly did, sending him a copy of the depositions and also all the facts at our disposal. In due course we received a letter from the Registrar that 